\title{
OPHIOBLENNIUS TRINITATIS (PISCES: BLENNIIDAE) FROM THE OCEANIC ARCHIPELAGOS OF SÃO PEDRO E SÃO PAULO, FERNANDO DE NORONHA AND ATOL DAS ROCAS*
}

\author{
Liana de Figueiredo Mendes \\ Universidade Federal do Rio Grande do Norte \\ Departamento de Botânica, Ecologia e Zoologia, Centro de Biociências \\ (Campus Universitário s/n, BR 101, 59072-970 Natal, RN, Brasil) \\ e-mail: liana_oceânica@yahoo.com.br
}

Descriptors: Morphotypes, Dispersion, Taxonomy, Blennies.

Descritores: Morfotipos, Dispersão, Taxonomia, Blenniidae.

The Blenniidae are a marine family composed of 53 genera and 345 species. They commonly occur in intertidal habitats, being dominant elements amongst the small benthic faunal fish that inhabit tropical reefs. Popularly known in Brazil as "peixes-macaco" (literally "monkey-fish") (CarvalhoFilho, 1999; Nelson, 1994), they are usually solitary in habit, hiding cryptically in burrows, corals and sponges, thus forming part of the invisible ichthyofauna which interacts with other resident organisms. The genus Ophioblennius has demersal egg laying habits within consolidated substrates and eclosion occurs in about 5 days (Marraro \& Nursall, 1983), with a long planktonic larval phase of approximately 50 days (Labelle \& Nursall, 1992). In Fernando de Noronha two distinct morphotypes have been found for the species $O$. trinitatis MirandaRibeiro, 1919. The distinguishing features between the two recognised groups (in both young and adult specimens) include colour differences, spatial distribution, behaviour and morphometrics. Until now just one morphotype has been registered in Atol das Rocas and São Pedro e São Paulo.

The present work deals with hypothetical population proximity between the 3 Archipelagos mentioned above. Results indicating possible affinities between populations can be associated with processes of dispersion and colonisation. The fish are being collected and examined using traditional taxonomic diagnostic methodology, complemented by studies of molecular biology, developed by the Universidade Federal do Rio Grande do Norte. This research project is part of a broader study, focusing on the settling of blennies in Brazilian oceanic islands.

Besides taxonomic information, data is being collected on the distribution and population density of these blennies, through a visual census.

Individuals are being examined according to the typical characteristics normally used for Ophiobllennius diagnosis which, basically comprise:

(*) Paper presented at the $2^{\text {nd }}$ Brazilian Congress of Oceanography, on 09-12 October, 2005. Vitória, Brazil. number of dorsal, anal and pectoral fin spines and soft rays (Springer, 1962; Menezes \& Figueiredo, 1985).

For distribution and population density analyses we have carried out visual censuses using $2 \mathrm{x}$ $2 \mathrm{~m}$ quadrat sampling in several types of substrata and along various depth ranges. Population counts were performed using about 60 quadrats in São Pedro and São Paulo, 50 in Atol das Rocas and 500 in Fernando de Noronha. The reason for examining a larger number of samples in Fernando de Noronha was that the population estimates there were made during the course of the author's doctoral research project, which included another 14 taxons (species of Blennioidei and Gobioidei). During the count, the total size of the adult and juvenile population was determined taking into consideration the different water depths in each sample. In all, 610 samples were taken. These censuses are being performed in tidal pools, coral reefs and seamounts. Visual censuses in $2 \times 2$ quadrats are indicated for sampling small fish and of cryptical behaviour (Bortone et al., 1986), as is the case of our target species

According to Muss et al. (2001) the species Ophioblennius trinitatis is the same as that occurring in mainland Brazil. However, these authors do not mention the occurrence of morphotypes nor the possible implications of such a fact. The following differences between adults $(O$. trinitatis 1$)$ and juveniles (O. trinitatis 2$)$ were recorded in Fernando de Noronha Archipelago:

i) Colour pattern: As to colour morphs the group considered as Ophioblennius trinitatis 1 possesses a homogenous dark brown colour pattern with yellow emarginated fins. This pattern changes to a heterogeneous colour with irregular twisted bands alternating between dark and light when subjected to stressful situations. Ophioblennius trinitatis 2 has a bi-coloured body with an olivaceous green dorsal region and pale yellow ventral region. In some cases the individual is totally yellow. 
ii) Behaviour: Specimens of Ophioblennius trinitatis 1 are less timid and aggressive than Ophioblennius trinitatis 2, exhibiting less speedy swimming behaviour and less escaping responses when in the presence of the observer. On several occasions individuals of Ophioblennius trinitatis 1 were observed occupying small areas (up to 6 fish in less than $1 \mathrm{~m}^{2}$ ), a situation never observed with Ophioblennius trinitatis 2.

iii) Distribution: Ophioblennius trinitatis 1 is always sighted in littoral areas and in tidal pools up to a maximum depth of $4 \mathrm{~m}$. On the other hand, Ophioblennius trinitatis 2 is only occasionally sighted in tidal pools, and generally occurs in the sub- tidal zone down to a depth of $53 \mathrm{~m}$.

iv) Morphometrics: The morphometric relation between length of the digestive tract/SL is different between the two groups, being 20\% greater in the case of Ophioblennius trinitatis 1. On the other hand, the average value of the caudal peduncle compression index is higher in Ophioblennius trinitatis 2 than in Ophioblennius trinitatis 1 . These results were obtained through the analyses of $40 O$. trinitatis 1 individuals and 40 O. trinitatis 2 individuals.

No distinct morphotypes were found for Ophioblennius trinitatis in either Atol das Rocas or São Pedro e São Paulo.

Colour differences observed in

Ophioblennius trinitatis 1 and 2 are attributed (Rylander \& Koster, 1982) to different life stages of these fish where these authors quote the coincidence of the same size ranges in the two types. They also state that the bi-coloured phase is typical of young fish. Currently there is no consistent evidence concerning this matter.

In the present paper we suggest that juveniles may be forced into deeper water by intra- and interspecific competition. The different frequency with which they are encountered in tidal pools is probably one main piece of evidence for this depth effect since both inter- and intra-specific competition is there in this scene of intense ecological pressure. It is also important to note that, in sub tidal environments, epibenthic microhabitats may be more available than in tidal pools considering the high organism diversity in intertidal ecosystem. The information obtained corroborates that of Bath (1990) who states that Ophioblennius larvae are frequently taken in the deep water column and maybe the adults are restricted to shallow waters.

As to the population densities in Fernando de Noronha, an average of 18 fish per $200 \mathrm{~m}^{2}$ was found in the case of Ophioblennius trinitatis 1 associated with many rocky holes, sponges and ascidians which may indicate a structurally complex habitat. In the case of Ophioblennius trinitatis 2 the figure was 14 fish $/ 200 \mathrm{~m}^{2}$ and the distribution was more diversified.

In São Pedro e São Paulo, the average population density reached 200 fish $/ 200 \mathrm{~m}^{2}$. This higher value is probably associated with the species' domination of the microhabitats since there are no potential competitors within its spatial realm.

As to blenniid dispersion the hypothesis of Pleistocene refuges is thoroughly discussed by Nunan (1992). It is known that the ichthyofauna of São Pedro e São Paulo (Lubbock \& Edwards, 1981; Feitoza, et al., 2003) has several species in common with the Brazilian mainland, the Caribbean and Africa and this possibly reflects the result of the dispersion and settling of larvae, mainly associated with ocean currents, since there are no seamount chains (Gorini \& Carvalho, 1982) that could, in the past, have contributed to colonization by these species. The fact that $O$. trintatis occurs in these oceanic islands and also along the Brazilian coastline, with long-lived larvae, supports the hypothesis that the dispersion of this species is mainly related to the pattern of ocean currents. Another argument reinforcing this hypothesis is the fact that the new Scartella species (Rangel \& Mendes, in prep.) from Fernando de Noronha and Atol das Rocas is phylogenetically closer to the African congeneric species, suggesting that the Benguela Current is an important factor in larval dispersion. Blenny dispersion could thus be more dependent upon water currents than on the Pleistocene stepping-stone theory.

Other known related cases should be investigated in order to possibly achieve more consistent paths for future research.

\section{ACKNOWLEDGMENTS}

To the CNPq for financial support; to Elenora Trajano my advisor during the development of my PhD Thesis; to the ONG Oceânica; to João Pedro Barreiros and Simone Marques for their comments; to IBAMA, Tamar and the administrative authorities of Fernando de Noronha; to the Marinha do Brasil and to all those people who helped with the field work.

\section{REFERENCES}

Bath, H. 1990. Blenniidae. In Quero, J. C.; J. C Hureau; C. Karrer; A. Post \& L. Saldanha eds. Check-list of the fishes of the eastern tropical Atlantic (CLOFETA). Lisboa; JNICT, SEI, Paris. UNESCO, 2:905-915.

Bortone, S. A.; Hastings, R. W. \& Oglesby, J. L. 1986. Quantification of reef fish assemblages: a comparison of several in situ methods. Northeast Gulf Science, 8(1):122.

Carvalho-Filho, A. 1999. Peixes: costa brasileira. 3. ed. São Paulo: Ed. Melro, 320 p. 
Feitoza, B. M.; Rocha, L. A.; Luiz-Júnior, O. J.; Floeter, S. R. \& Gasparini, J. L. 2003. Reef fishes of St. Paul's Rocks: new records and notes on biology and zoogeography. Aqua, J. Ichth. Aqua. Biol. ,7(2)-82p.

Gorini, M. A. \& Carvalho, J. C. 1982. Geologia da margem continental inferior brasileira e do fundo oceânico adjacente. In: Schobbenhaus, C. eds. Geologia do Brasil. Brasilia: Ministério das Minas e Energia, $501 \mathrm{p}$.

Labelle, M. \& Nursall, J. R. 1992. Population biology of the redlip blenny, Ophioblennius trinitatis macclurei (Sylvester) in Barbados. Bull. Mar. Sci., 50:186-204.

Lubbock, R. \& Edwards, A. 1981. The fishes of Saint Paul's rocks. J. Fish Biol., 18:135-157.

Marraro, C. H. \& Nursall, J. R. 1983. The reproductive periodicity and behaviour of Ophioblennius trinitatis (Pisces: Blenniidae) at Barbados. Can. J. Zool., 61:317325 .

Menezes, N. A. \& Figueiredo, J. L. 1985. Manual de peixes marinhos do sudeste do Brasil. Teleostei. v.4. São Paulo: Museu de Zoologia ,USP, 105 p.

Muss, A.; Robertson, D. R.; Stepien, C. A.; Wirtz, P. \& Bowen, B. W. 2001. Phylogeography of Ophioblennius: the role of ocean currents and geography in reef fish evolution. Evolution, 55(3):561-572.
Nelson, J. S. 1994. Fishes of the world. New York: John Willey \& Sons, p.523.

Rylander, M. K. \& Koster, F. 1982. Observations on the biology of the redlip blenny Ophioblennius trinitatis (Pisces:Blenniidae) on the Colombian coast of the Caribbean. An. Inst.Investnes mar., Punta de Betin., 12:105-115.

Springer, V. G. 1962. A review of the Blenniid fishes of the genus Ophioblennius Gill. Copeia, 426-433.

Sources of Unpublished Material

Nunan, G. 1992. Composition, species distribution and zoogeographical affinities of the Brazilian reef-fish fauna. PhD. Thesis, University of Newcastle upon Tyne, United Kingdom.

(Manuscript received 16 December 2005; revised 22 March 2006; accepted 21 December 2006) 